\title{
Composición química, digestibilidad y cinética ruminal de la digestión de residuos agrícolas tratados con explosión de vapor
}

\section{Chemical composition, digestibility and digestion kinetics of steam explosion-treated crop residues}

\author{
Ricardo Basurto Gutiérreza, Agustín Escamilla Martínez ${ }^{\mathrm{b}}$, Sergio Moya Vegac ${ }^{\mathrm{c}}$, Ericka \\ Ramírez Rodríguez ${ }^{\mathrm{a}}$, Juan Becerra Becerra ${ }^{\mathrm{a}}$
}

\begin{abstract}
RESUMEN
Para determinar el efecto de la explosión de vapor (EXPV) en la composición y digestibilidad de forrajes toscos (F) se condujeron dos experimentos. En el Exp 1, con un diseño factorial de presión (P; 10.3, 13.8 y $17.2 \mathrm{~kg} \mathrm{~cm}{ }^{2}$ ) y tiempo (T; 5,10 y 15 min), se determinaron los cambios en pH, fracciones de fibra (FF) y la digestibilidad in vitro (DIVMS) del rastrojo de sorgo (RS), rastrojo de maíz (RM) y bagazo de caña (BZC) por efecto de EXPV. En el Exp 2, se comparó la cinética de la digestión in situ (CDI) de forrajes sin tratar y tratados con EXPV, RS y RM fueron tratados con $13.8 \mathrm{~kg} / \mathrm{cm}^{2}$ por $10 \mathrm{~min}$ y BZC con $17.2 \mathrm{~kg} / \mathrm{cm}^{2}$ por $15 \mathrm{~min}$. Se incubaron muestras de forraje en rumen hasta por $120 \mathrm{~h}$. Los datos fueron ajustados a un modelo no lineal. $P$ y $T$ no interactuaron en $\mathbf{p H}$ o FF. El aumento en $P$ o $T$ redujeron el $\mathbf{p H}$, FDN y la hemicelulosa. La lignina y FDA no cambiaron dentro los niveles de $\mathbf{P}$ o $\mathrm{T}$. En DIVMS, $\mathrm{P} * \mathbf{F}$ y $\mathrm{T} * \mathrm{~F}$ fueron significativas. EXPV incrementó las fracciones soluble y potencialmente digestible y extensión de digestión de FF de los tres forrajes. Exceptuando para BCZ, el tiempo de retraso no cambió para FF. La respuesta de la tasa de digestión fue variable para FF o forraje. Se concluye que la EXPV mejora la calidad nutritiva de los forrajes toscos por solubilizar parte de la pared celular, acelerar la tasa de digestión e incrementar la extensión de la digestión.
\end{abstract}

PALABRAS ClAVE: Explosión de vapor, Forrajes toscos, Fibra, Digestibilidad, Cinética digestiva.

\begin{abstract}
Two experiments were conducted to determine the effects of steam explosion (STE) on chemical composition and digestibility of the following forages (F): sorghum stover (SOS), corn stover (COS) and sugarcane bagasse (SUB). The Exp 1 was conducted to determine the effects of STE on $\mathrm{pH}$, fiber fractions (FF) and in vitro digestibility (IVDMD). Fifty four samples were generated using a RCB design with a $3 * 3 * 3$ factorial treatment arrangement, where the factors were: pressure $\left(P: 10.3,13.8\right.$ and $\left.17.2 \mathrm{~kg} / \mathrm{cm}^{2}\right)$, time (T: 5, 10 and $15 \mathrm{~min}$ ) and F (SOS, COS and SUB). In Exp 2, changes in the digestion kinetics were determined when using the combinations of $P$ and $T$ that maximized IVDMD; thus, SOS and COS were treated at $13.8 \mathrm{~kg} / \mathrm{cm}^{2}$ for $10 \mathrm{~min}$, and $\mathrm{SUB}$ at $17.2 \mathrm{~kg} /$ $\mathrm{cm}^{2}$ for $15 \mathrm{~min}$. The treated and non-treated samples were incubated in rumen for up to $120 \mathrm{~h}$. Data were fitted to a nonlinear model. No significant interactions $T * P$ or $F * P * T$ were detected on $\mathbf{p H}$ or $\mathbf{F F}$; however, as $\mathbf{P}$ or $\mathbf{T}$ increased, $\mathbf{p H}$, NDF and hemicellulose decreased. Lignin or ADF were not affected by $P$ or $T$. As for IVDMD concerns, $P * F$ and $F * T$ interactions were significant. STE increased soluble fraction and degree of $F$ digestion. Only lag time of SUB was reduced by STE. The potential digestible fraction was reduced in SOS and COS. It was concluded that the changes in chemical composition and digestion kinetics are related mainly to cell wall solubilization by stem explosion.
\end{abstract}

KEY WORDS: Steam-explosion, Crop residues, Fiber, Digestibility, Digestion kinetics.

Recibido el 21 de junio de 2011. Aceptado el 23 de octubre de 2011

a Centro Nacional de Investigación Disciplinaria en Fisiología Animal, INIFAP. Km 1 Carretera a Colón, Ajuchitlán, 76280, Colón, Querétaro. México. basurto.ricardo@inifap.gob.mx. Correspondencia al primer autor.

b Centro de Investigaciones Avanzadas del Estado de Querétaro.

c Facultad de Ciencias Naturales, Universidad Autónoma de Querétaro.

Proyecto financiado por CONACYT-SAGARPA 2004. No.0182. 


\section{INTRODUCCIÓN}

Con base en la superficie cosechada de cereales y que por cada kilogramo de grano producido se genera un kilogramo de rastrojo o paja $(1)$, se puede estimar que la disponibilidad de los residuos agrícolas para la alimentación directa de rumiantes en México fue alrededor de 23.5 millones de toneladas anuales en 2008. Empleando el nivel uno del programa del $\mathrm{NRC}^{(2)}$, que es utilizado para determinar los requerimientos de proteína y energía, se puede estimar que esta cantidad de esquilmos es suficiente para mantener aproximadamente 10 millones de vacas secas, equivalente a un tercio del inventario nacional bovino. No obstante, un incremento de sólo $10 \%$ en la digestibilidad de estos residuos agrícolas, equivale a la energía de mantenimiento de 0.6 millones de vacas. Por esto es indudable la importancia de continuar evaluando métodos para el mejoramiento de la digestibilidad de los residuos agrícolas.

Los tres principales componentes de las paredes celulares son la celulosa, la hemicelulosa y la lignina. La hemicelulosa es un polisacárido insoluble en agua, pero soluble en ácidos o álcalis, y se encuentra estrechamente ligado a la lignina ${ }^{(3)}$. La hemicelulosa y la lignina forman una red hidrofóbica, en la cual las micro-fibrillas de celulosa están embebidas(4). La red restringe el acceso de las bacterias y de enzimas celulolíticas hacia las micro-fibrillas. Otros factores documentados que limitan el acceso enzimático son los grupos acetilo de la hemicelulosa ${ }^{(5)}$, el índice de cristalización de las micro-fibras de celulosa(6) y la superficie disponible para el acceso enzimático(7).

Los tratamientos químicos tienen como objetivo romper la unión entre los carbohidratos estructurales y la lignina $(3,8,9)$, lo que resulta en una mayor digestibilidad de las fracciones de fibra y un mayor consumo voluntario(10). El incremento en el consumo de alimento puede deberse a que el tamaño de las partículas de forraje tratado decrecen más rápidamente durante la rumia que el tamaño de las partículas de forraje $\sin \operatorname{tratar}^{(3,10)}$.

\section{INTRODUCTION}

Based on the harvested area of cereals and that for every kilogram of grain produced generates a kilogram of stubble or straw(1), we can estimate that the availability of agricultural residues for direct feeding of ruminants in Mexico was about 23.5 million tons in 2008. Using a level one program of the $\operatorname{NRC}^{(2)}$, which is used to determine their protein and energy requirements, we can estimate that this amount of grain harvest is sufficient to maintain approximately 10 million dry cows, equivalent to one third of the national cattle inventory. However, an increase of only $10 \%$ in the digestibility of these agricultural residues, produce the energy equivalent to keeping 0.6 million cows. That is undoubtedly important to evaluate methods for improving the digestibility of crop residues.

The three main components of the cell walls are cellulose, hemicellulose and lignin. The hemicellulose is a polysaccharide insoluble in water but soluble in acids or alkalis and is closely linked to lignin ${ }^{(3)}$. The hemicellulose and lignin form a hydrophobic grid, in which the micro fibrils of cellulose are embedded(4). The network restricts access of bacteria and cellulolytic enzymes to the micro fibrils. Other factors that have been documented to limit enzyme access are acetyl groups of hemicellulose ${ }^{(5)}$, the rate of crystallization of the cellulose microfibers $(6)$ and the surface available for enzyme access $(7)$.

The chemical treatments are intended to break the bond between the structural carbohydrates and lignin $(3,8,9)$, resulting in a greater digestibility of the fiber fractions and increased voluntary intake ${ }^{(10)}$. Feed intake increases because the size of particles of treated forage decreases more rapidly than the size of particles of untreated forage during rumination $(3,10)$.

However, the cost of chemicals, the requirement of trained personnel to handle chemicals and chemical residues in the treated material has limited the adoption of chemical methods for the treatment of agricultural waste. Hence, the importance of 
No obstante, el costo de las sustancias químicas, el requerimiento de personal entrenado para el manejo de los químicos y la presencia de residuos químicos en el material tratado, ha limitado la adopción de los métodos químicos para el tratamiento de los residuos agrícolas. De aquí, la importancia de seguir explorando métodos que no dependan del uso de compuestos químicos para mejorar la calidad de los forrajes toscos.

Uno de estos métodos es el tratamiento con presión y vapor saturado de agua, seguido de la despresurización súbita del sistema, conocido como explosión de vapor (EXPV). El proceso se basa en la acción hidrolítica del vapor a altas temperaturas que hidroliza los enlaces lignino-celulolíticos, la solubilización de la hemicelulosa y eliminación de los grupos acetilo(11).

Adicionalmente, durante la súbita despresurización, la estructura de la pared celular es alterada(12) y la lignina es re-localizada sobre la superficie de las fibras de celulosa(13), lo cual resulta en una mayor área expuesta para la adhesión de los microbios del rumen. Esto podría resultar en una mayor tasa de digestión o extensión de la digestión.

El método de EXPV es ampliamente utilizado como pre-tratamiento en la producción de papel y de etanol $(14,15,16)$. De acuerdo a Nakamura, et al ${ }^{(17)}$, la mayor disponibilidad de los carbohidratos estructurales para la fermentación microbiana se logra a los $36.7 \mathrm{~kg} / \mathrm{cm}^{2}$ de presión por $2 \mathrm{~min}$, lo que maximiza la producción de etanol.

Sin embargo, estos niveles de presión no son fácilmente manejables a una escala de empresa pequeña. Por lo anterior, ha sido preferible manejar presiones de vapor menores en combinación con mayores tiempos de aplicación(18). Hart et al(19) reportaron que los mejores resultados se encontraron con presiones alrededor de $21.1 \mathrm{~kg} \mathrm{~cm}^{2}$ por 1.5 min para tratamiento de paja de arroz, bagazo de caña y residuos de la cosecha de la caña para la alimentación animal. No se encontraron referencias evaluate methods that do not depend on the use of chemicals to improve the quality of roughage.

One such method is the treatment with pressure and water, saturated steam, followed by sudden depressurization system, known as steam explosion (STE). The process is based on the hydrolytic action of steam at high temperatures that hydrolyze the lignin-cellulolytic, solubilization of the hemicellulose and removal of the acetyl groups $(11)$.

Additionally, during the sudden depressurization, the cell wall structure is impaired ${ }^{(12)}$ and lignin is relocated on the surface of the cellulose fibers(13), which results in a greater surface area for adhesion of the rumen microbes. This could result in increased digestion rate or extent of digestion.

STE method is widely used as pretreatment in the production of paper and ethanol $(14,15,16)$. According to Nakamura et al(17), the increased availability of structural carbohydrates for microbial fermentation is achieved at $36.7 \mathrm{~kg} / \mathrm{cm}^{2}$ pressure for $2 \mathrm{~min}$, which maximizes the ethanol production.

However, these pressure levels are not easily manageable in small scale business; therefore, it has been preferred to handle lower vapor pressures in combination with longer application ${ }^{(18)}$. Hart et $a l(19)$ reported best results at pressures around 21.1 $\mathrm{kg} \mathrm{cm}{ }^{2}$ for $1.5 \mathrm{~min}$ for treatment of rice straw, sugarcane bagasse and sugarcane crop residue for animal feeding. There were no references in Mexico to the use of steam as a treatment method.

The aim of this study was to determine the effect of steam explosion treatment (STE) at different pressures and time of application, the composition of the fractions of fiber, in vitro digestibility and in situ digestion kinetics of low quality forages.

\section{MATERIALS AND METHODS}

The study was conducted at the facilities of National Center for Disciplinary Research in Physiology and Animal Improvement, located in Ajuchitlán, Colon, 
sobre el uso de vapor como método de tratamiento en México.

El objetivo del presente estudio fue determinar el efecto del tratamiento explosión de vapor (EXPV) a diferentes presiones y tiempos de aplicación, sobre la composición de las fracciones de fibra, la digestibilidad in vitro y la cinética de digestión in situ de forrajes de baja calidad nutricional.

\section{MATERIALES Y MÉTODOS}

El estudio se realizó en las instalaciones del Centro Nacional de Investigación Disciplinaria en Fisiología y Mejoramiento Animal, ubicado en Ajuchitlán, Colón, Querétaro, México, y constó de dos pruebas experimentales.

En el Exp 1 se determinó el efecto de la combinación de presión y tiempo sobre los cambios en la composición química y la digestibilidad in vitro de forrajes toscos. Los forrajes se trataron en un reactor de 10 L de capacidad, el cual se diseñó y construyó en el Centro de Investigaciones Avanzadas, CIATEQ. El reactor piloto se alimentó con vapor, el cual se generó al calentar un depósito de agua hasta alcanzar las presiones establecidas en el protocolo experimental. La despresurización súbita del sistema o explosión de vapor, se realizó manualmente abriendo una válvula para dejar escapar el vapor de agua del reactor. El sistema contaba con un medidor de presión de resorte y el control de la presión dentro del sistema se realizó regulando manualmente el tamaño de la flama.

Los forrajes estudiados fueron: rastrojo de sorgo (RS), rastrojo de maíz (RM) y bagazo deshidratado de caña (BZC). Los residuos de RS y RM se molieron con un molino de martillo utilizando una criba $2.54 \mathrm{~cm}$. El BZC se transportó húmedo desde el ingenio, y posteriormente se deshidrató en una estufa de aire forzado en las instalaciones del CIATEQ. Debido a la diferencia en la densidad y al tamaño de la partícula de los forrajes en el estudio, el tamaño de muestra a tratar varió entre forrajes, 750, 550 y $700 \mathrm{~g}$ por lote para RS, RM y BZC, respectivamente.
Queretaro, Mexico and consisted of two experimental trials.

In Exp 1, the effect of the combination of pressure and time on changes in chemical composition and in vitro digestibility of roughages was studied. Forages were treated in a $10 \mathrm{~L}$ capacity reactor, which was designed and built at the Center for Advanced Research, CIATEQ. The pilot reactor was fed with steam, which was generated by heating a water tank up to the pressures established in the experimental protocol. Sudden depressurization system or steam explosion was performed manually by opening a valve to allow water vapor to escape from the reactor. The system had a pressure gauge spring, and pressure control within the system is performed manually by adjusting the size of the flame.

Forages used were sorghum stover (SOS), corn stover (COS) and dehydrated sugarcane bagasse (SUB). SOS and COS residues were ground with a hammer mill using a $2.54 \mathrm{~cm}$ sieve. The wet SUB was transported from the mill, so it was dehydrated in a forced air oven at CIATEQ facilities. Due to the difference in density and particle size of fodder, the sample size to be treated varied between fodder, 750, 550 and $700 \mathrm{~g}$ per batch for SOS, COS and SUB, respectively.

Experiment 1. Changes in the chemical composition and in vitro digestibility

The pressures used in the study were 10.3, 13.8 and $17.2 \mathrm{~kg} / \mathrm{cm}^{2}$. Once pressure was reached, it remained constant for 5, 10 and $15 \mathrm{~min}$. At the end of this time, the system was suddenly depressurized. The reactor was manually opened, and the material removed, which was transported to the laboratory and placed in trays for dry matter determination at $55{ }^{\circ} \mathrm{C}$ for $72 \mathrm{~h}$. Dried samples were ground with a $2 \mathrm{~mm}$ sieve in a Wiley mill. The ground samples were kept in polyethylene bags until chemical analysis. Additionally, $\mathrm{pH}$ of the wet material was recorded.

Because of combinations of vapor pressure and temperature have varied among studies, to make 
Experimento 1. Cambios en la composición química y la digestibilidad in vitro

Las presiones utilizadas en el estudio fueron 10.3, 13.8 y $17.2 \mathrm{~kg} / \mathrm{cm}^{2}$. Una vez alcanzada la presión, ésta se mantuvo constante durante 5,10 y 15 min. Al final de estos tiempos, el sistema se despresurizó súbitamente. Se abrió manualmente el reactor y se retiró el material, el cual se transportó al laboratorio y se colocó en bandejas para la determinación de la materia seca a $55{ }^{\circ} \mathrm{C}$ por $72 \mathrm{~h}$. Las muestras secas se molieron con una criba de $2 \mathrm{~mm}$ con un molino tipo Wiley. Las muestras molidas se mantuvieron en bolsas de polietileno hasta su análisis químico. Adicionalmente, se registró el $\mathrm{pH}$ del material húmedo.

Debido a que las condiciones de tiempo, presión de vapor y la temperatura utilizados han variado considerablemente entre estudios, nos permite hacer comparaciones directas. Walsum ${ }^{(20)}$ propuso una ecuación, $\log (\mathrm{S})=$ Tiempo $(\min ) * \exp$ ((Temperatura-100)/14.5), que combina los efectos de tiempo y temperatura para obtener la severidad (S) del tratamiento hidro-térmico. Aunque en el presente estudio, no se midió la temperatura dentro del reactor, es posible estimarla por medio de la presión de vapor y con el uso de tablas de vapor(21). Así, las severidades estimadas para presión de vapor $10.3 ; 13.8$ y $17.2 \mathrm{~kg} \mathrm{~cm}^{2}$ dentro de tiempo de aplicación fueron: $5 \mathrm{~min}(3.1,3.4,3.6)$; $10 \mathrm{~min}$ $(3.5,3.8,4.0)$ y $15 \min (3.8,4.1,4.3)$, respectivamente.

El diseño experimental fue de bloques (2) completos al azar con un arreglo factorial $3 * 3 * 3(22)$. Se consideró como bloque, la sesión donde se generaron muestras de todas las combinaciones de los factores de estudio: Forraje (F), Tiempo (T) y Presión (P). En cada sesión, la secuencia se realizó en forma aleatoria para generar las combinaciones $(\mathrm{F} * \mathrm{~T} * \mathrm{P})$. Por cada combinación de $\mathrm{F} * \mathrm{~T} * \mathrm{P}$ se realizó una sola repetición dentro de cada sesión.

Para la determinación de la digestibilidad in vitro, $0.25 \mathrm{~g}$ de muestra de los residuos agrícolas tratados o sin tratar se colocaron en bolsas de fibra F57 the results comparable is necessary to use the equation proposed by Walsum ${ }^{(20)}: \log (\mathrm{S})=$ Time $(\min ) * \exp (($ temperature -100$) / 14.5)$, which combines the effects of application time and temperature to give a severity score (S) of hydrothermal treatment. Although in the present study, the temperature inside the reactor was not measured, it was possible to estimate it by means of vapor pressure and with the use of steam tables $(21)$. Thus, the severities of vapor pressure estimated for 10.3, 13.8 and $17.2 \mathrm{~kg} \mathrm{~cm}^{2}$ in application time were 5 $\min (3.1,3.4,3.6) 10 \min (3.5,3.8,4.0)$ and 15 $\min (3.8,4.1,4.3)$, respectively.

The experiment was a random complete (2) block design with a $3 * 3 * 3$ factorial arrangement $(22)$. Block was the session that generated samples of all combinations of the factors: Forage (F), Time (T) and Pressure (P). In each block, the sequence was randomized to generate the combinations $\left(\mathrm{F}^{*} \mathrm{~T} * \mathrm{P}\right)$. For each combination of $\mathrm{F} * \mathrm{~T} * \mathrm{P}$, a single repetition was carried out within each block. A $0.25 \mathrm{~g}$ sample of agricultural waste treated, or untreated, were placed in a fiber F57 bag (Ankom Technology Corp., Macedon NY), previously treated with acetone, for determining in vitro true digestibility(23). Two bags per sample were incubated for $48 \mathrm{~h}$ at $39^{\circ} \mathrm{C}$ with a mixture of buffer solution (pH 6.8) and rumen fluid in a Daisy Incubator (Ankom Technology Corp., Macedon, NY). Rumen fluid was obtained from two cows grazing a native grass prairie. At the end of the period, the bags were removed from the incubator, rinsed under running water, and cooling to stop microbial activity. Then, the bags with residues were extracted with neutral detergent solution in Ankom ${ }^{200}$ fiber analyzer (Ankom Technology Corp., Macedon, NY) to remove microbial debris or any remaining soluble fraction..

Treatment effect was measured as the difference between the concentrations of the chemical fraction in the untreated material, minus the concentration in the treated material, measured in percentage units (PU).

For the analysis of variance, a statistical model that included: block, pressure $(\mathrm{P})$, time $(\mathrm{T})$, feed $(\mathrm{F})$ 
(Ankom Technology Corp., Macedon NY) que previamente habían sido tratadas con acetona. Dos bolsas por muestra se incubaron durante $48 \mathrm{~h}$ a 39 ${ }^{\circ} \mathrm{C}$ con una mezcla de solución amortiguadora $(\mathrm{pH}$ 6.8) y líquido del rumen en un equipo Daisy de Ankom (Ankom Technology, Macedon, NY). El líquido ruminal se obtuvo de dos vacas que pastoreaban una pradera de pasto nativo. Al final del período, las bolsas fueron retiradas del fermentador, se enjuagaron con agua corriente $y$, se colocaron en refrigeración para detener la actividad microbiana. Se realizó la extracción en solución fibra neutro detergente para obtener un estimado de la digestibilidad verdadera(23).

El efecto del tratamiento se midió como la diferencia entre la concentración de la fracción química en el material sin tratar, menos la concentración en el material tratado, medido en unidades porcentuales (UP).

Para el análisis de varianza, el modelo estadístico incluyó: bloque, presión $(\mathrm{P})$, tiempo $(\mathrm{T})$, forraje (F) y las interacciones: $\mathrm{P} * \mathrm{~T}, \mathrm{P} * \mathrm{~F}, \mathrm{~T} * \mathrm{~F}$ y $\mathrm{P} * \mathrm{~T} * \mathrm{~F}$. Se utilizó el procedimiento para modelos lineales generales del paquete estadístico de $\mathrm{SAS}^{(24)}$, y contrastes ortogonales para determinar la tendencia lineal (l $\left.\begin{array}{lll}1 & 0 & 1\end{array}\right)$ o cuadrática ( $\left(\begin{array}{lll}1 & -2 & 1\end{array}\right)$ de los factores $\mathrm{P}$ y $\mathrm{T}$.

Experimento 2. Cambios en la cinética de la digestión in situ

Se condujo una prueba con animales con cánulas en el rumen. Se seleccionó la combinación de presión y tiempo que resultó con el valor mayor de digestibilidad in vitro en el Exp 1, por lo que los tratamientos seleccionados fueron: presión de 13.8 $\mathrm{kg} \mathrm{cm}{ }^{2}$ de vapor saturado por 10 min para $\mathrm{RM} \mathrm{y}$ $\mathrm{RS}$, y presión de $17.2 \mathrm{~kg} \mathrm{~cm}^{2}$ durante 15 min para BZC. También se determinó la cinética de digestión de los forrajes sin tratar.

Durante seis semanas, tres vacas Holstein (540 \pm $50 \mathrm{~kg}$ ), provistas con una cánula en rumen (Bar Diamond, INC; diámetro interno $10 \mathrm{~cm}$ ) se alojaron individualmente. Los animales recibieron como and interactions: $\mathrm{P} * \mathrm{~T}, \mathrm{P} * \mathrm{~F}, \mathrm{~F} * \mathrm{~T}$ and $\mathrm{P} * \mathrm{~T} * \mathrm{~F}$. General linear models procedure of SAS statistical package ${ }^{(24)}$ were used. Orthogonal contrasts were used to determine the linear trend $\left(\begin{array}{lll}1 & 0 & 1\end{array}\right)$ or quadratic (1 - -21$)$ of the $\mathrm{P}$ and $\mathrm{T}$ factors.

Experiment 2. Changes in kinetics parameters of in situ digestion

The combination of pressure and time, which resulted with the higher value in the in vitro true digestibility for forage in Exp 1, was selected. So treatments were: three steam-explosion treated crop residues: COS and SOS treated at $13.8 \mathrm{~kg} \mathrm{~cm}^{2}$ of saturated steam pressure for $10 \mathrm{~min}$; and SUB treated at $17.2 \mathrm{~kg} \mathrm{~cm}^{2}$ of saturated steam pressure for $15 \mathrm{~min}$ for dehydrated cane bagasse (SUB) and the three untreated crop residues.

For 6 wk, three Holstein cows $(540 \pm 50 \mathrm{~kg})$, fitted with a rumen cannula (Bar Diamond, Inc., internal diameter $10 \mathrm{~cm}$ ), were housed individually. Animals were fed with a mixture of alfalfa hay and native grasses hay. The mixture contained $11.5 \%$ crude protein and was offered at $2.0 \%$ (DM basis) of live weight of animals. Additionally, the animals had ad libitum access to water and a mineral block (1\% S, 1,300 ppm of Mn, Zn 1,100 ppm, 185 ppm $\mathrm{Cu}, 14 \mathrm{ppm}$ Fe, 5 ppm of I, 5 ppm of Co, 1,100 ppm of Se).

Sequence of incubation in each animal was randomized. Only a series of a treatment was incubated at a time in the rumen of each cow. At the end, three replicates were obtained for each forage treated or untreated.

The untreated and treated forages were ground through a $2 \mathrm{~mm}$ sieve and $14.5 \mathrm{mg}$ of ground sample per $\mathrm{cm}^{2}$ of surface ${ }^{(25)}$ were placed in $10 \mathrm{x}$ $20 \mathrm{~cm}$ dacron bags (Ankom Technology Corp., Macedon NY). The bags were heat sealed and the seal was tested right before incubating the samples.

Prior insertions in the rumen, the bags were immersed in hot water $\left(39{ }^{\circ} \mathrm{C}\right)$ for 15 to $20 \mathrm{~min}$. Each set of bags was placed inside a nylon bag 
alimento una mezcla de heno de alfalfa y heno de pradera compuesta por pastos nativos. La mezcla contenía $11.5 \%$ de proteína cruda y se ofreció al $2.0 \%$ del peso vivo de los animales. Adicionalmente, los animales tuvieron libre acceso a agua y a un bloque mineral $(1 \% \mathrm{~S}, 1,300 \mathrm{ppm}$ de $\mathrm{Mn}, 1,100 \mathrm{ppm}$ de $\mathrm{Zn}, 185 \mathrm{ppm}$ de $\mathrm{Cu}, 14 \mathrm{ppm}$ de Fe, 5 ppm de I, 5 ppm de Co, 1,100 ppm de $\mathrm{Se})$.

En cada animal, la secuencia en la cual se incubaron los tratamientos fue aleatorizada. Una serie y un tratamiento, fueron incubados a la vez en el rumen de cada vaca. Al final, se obtuvieron tres repeticiones por cada uno de los seis tratamientos.

Después de que las muestras fueron molidas a través de una criba de $2 \mathrm{~mm}$, se colocaron $14.5 \mathrm{mg}$ de muestra por $\mathrm{cm}^{2}$ de superficie(25) en bolsas de dacrón de 10 x $20 \mathrm{~cm}$ (Ankom Technology Corp., Macedon NY), las cuales se sellaron con calor y se probó que el sellado estuviera correcto antes de incubar las muestras.

Previo a la inserción en el rumen, las bolsas se sumergieron en agua caliente $\left(39^{\circ} \mathrm{C}\right)$ por 15 a 20 min. Cada serie de bolsas se colocó dentro de un saco de nylon con perforaciones, el cual contenía un peso metálico entre 250 a $300 \mathrm{~g}$. El saco se mantuvo fijo a la cánula del rumen mediante un cordón de nylon de $60 \mathrm{~cm}$ de longitud. El saco se insertó en el saco ventral del rumen previo a la alimentación (0800 h).

Los tiempos de incubación fueron: $0,2,4,8,12$, $18,24,36,48,60,72,96$ y $120 \mathrm{~h}$ y se obtuvieron dos bolsas en cada tiempo de incubación. Las bolsas se lavaron ligeramente con agua corriente y se revisaron para detectar defectos en el sellado o rasgaduras de la tela. Las bolsas con defectos se eliminaron. El resto de las bolsas se mantuvieron en congelación a $-20{ }^{\circ} \mathrm{C}$ hasta su procesamiento al final de la prueba.

Al final del período experimental, las bolsas se descongelaron en un refrigerador durante toda la noche y, posteriormente, se terminó la descongelación with holes, which contained a metal weight from 250 to $300 \mathrm{~g}$. The bag was held fixed to the rumen cannula with a $60 \mathrm{~cm}$ nylon cord. The bag was inserted into the rumen ventral area prior to feeding (0800 h).

Incubation times were $0,2,4,8,12,18,24,36$, 48, 60, 72, 96 and $120 \mathrm{~h}$, and two bags in each incubation time were obtained. The bags were washed in running water and inspected for defects in the sealing or tears in the fabric, removing defective bags. The remaining bags were frozen at $-20{ }^{\circ} \mathrm{C}$ until processing at the end of the test.

At the end of the experimental period, the bags were thawed in a refrigerator overnight and then defrosting was completed at room temperature. Then, the bags were washed in an automatic washing machine and dried at $55^{\circ} \mathrm{C}$ for $48 \mathrm{~h}$ in a forced air oven ShelLab (Mod FX28-2, Sheldon Manufacturing, Inc.). The remaining residues in bags composed by treatment, time, and animal were mixed prior to laboratory analysis.

The model (26) to estimate the kinetics of digestion of the fibrous fractions was: digestibility (D), \%= $\mathrm{A}+\mathrm{FPD} *(1-\exp (-\mathrm{k} *(\mathrm{~T}-\mathrm{LT}))$, where A, FDP, LT and $\mathrm{k}$ are the fraction which disappears in $\mathrm{T}=$ 0 , the potentially digestible fraction, lag time and digestion rate $\left(\% \mathrm{~h}^{-1}\right)$, respectively. The extension of digestion was the chemical fraction which disappears at $120 \mathrm{~h}$ of incubation.

NLIN procedure of the SAS package was used to estimate the parameters of the kinetics of digestion(24). To determine the change in the parameters by STE effect, the model was reparameterized according to Schabenberger and Pierce(27). NLIN procedure has a significant preestablished alpha level $=0.05$.

Dry matter $\left(100{ }^{\circ} \mathrm{C}\right.$ overnight), organic matter $(600$ ${ }^{\circ} \mathrm{C}$ for $4 \mathrm{~h}$ ), the fiber and lignin fractions of $72 \%$ $\mathrm{H} 2 \mathrm{SO} 4(28)$ were performed at the laboratory. Hemicellulose was calculated as the difference between NDF and ADF contents. The $\mathrm{pH}$ of untreated and treated residues were performed 
a temperatura ambiente. En seguida, las bolsas se lavaron en una máquina lavadora automática, y luego se secaron a $55^{\circ} \mathrm{C}$ por $48 \mathrm{~h}$ en una estufa de aire forzado ShelLab (Mod. FX28-2; Sheldon Manufacturing, Inc). Los residuos correspondientes a las bolsas por tratamiento, tiempo y animal se mezclaron previo a su análisis en el laboratorio.

El modelo ${ }^{(26)}$ para estimar la cinética de digestión de las fracciones fibrosas fue: digestibilidad (D), $\%=$ $\mathrm{A}+\mathrm{FPD}^{*}\left(1-\exp ^{\left(-\mathrm{k}^{*}(\mathrm{~T}-\mathrm{TT})\right.}\right)$, donde A, FDP, TT y k son: la fracción que desaparece en el $\mathrm{T}=0$, la fracción potencialmente digestible, tiempo de retraso y la tasa de digestión $\% \mathrm{~h}^{-1}$, respectivamente. La extensión de la digestión se consideró como la fracción química que desparece a las 120 h de incubación.

Para estimar los parámetros de la cinética de digestión se utilizó el procedimiento NLIN del paquete SAS (24). Para determinar el cambio en los parámetros por efecto de la EXPV, el modelo se re-parametrizó según lo sugieren Schabenberger y Pierce ${ }^{(27)}$. El procedimiento de NLIN tiene un nivel de significancia alfa $=0.05$ pre-establecido.

Cuadro 1. Composición química de los forrajes sin tratar en el presente estudio

Table 1. Chemical composition of untreated forages in the present study

\begin{tabular}{lccc}
\hline $\begin{array}{l}\text { Analytic } \\
\text { fraction }\end{array}$ & $\begin{array}{c}\text { Corn } \\
\text { stover }\end{array}$ & $\begin{array}{c}\text { Sorghum } \\
\text { stover }\end{array}$ & $\begin{array}{c}\text { Sugarcane } \\
\text { bagasse }\end{array}$ \\
\hline Dry matter, \% & 93.5 & 93.1 & 93.8 \\
$\mathrm{pH}$ & 7.52 & 6.52 & 6.29 \\
\multicolumn{3}{c}{ Dry base, \% DM } & \\
Organic matter & 89.0 & 82.8 & 91.9 \\
Crude protein (Nx6.25) & 3.29 & 2.72 & 1.24 \\
Neutral detergent fiber & 76.29 & 69.91 & 89.15 \\
Acid detergent fiber & 51.58 & 50.56 & 64.37 \\
Hemicellulose & 24.71 & 19.35 & 24.78 \\
Cellulose & 41.3 & 38.8 & 49.6 \\
Lignin $\left(70 \% \mathrm{H}_{2} \mathrm{SO}_{4}\right)$ & 5.23 & 6.06 & 12.18 \\
IVDDM, \% & 61.32 & 59.55 & 34.17 \\
\hline
\end{tabular}

IVDDM= in vitro digestibility of dry matter. according to Tejada(29) with the use of a potentiometer (Orion 720A Mod) calibrated in the range from 4 to 7 .

\section{RESULTS AND DISCUSSION}

Table 1 shows the chemical composition of untreated agricultural residues. It is appreciated that the three fodders had a high content of neutral detergent fiber, especially the SUB, over $89 \%$ of the dry matter. Consistent with the high fiber has low in vitro digestibility (DMIVD) vs COS or SOS. However, DMIVD coefficients for COS and SUB are higher than those reported previously $(30,31)$. This difference may be explained because the Ankom filter bags method gives higher digestibility values than the tube method of Tilley and Terry(32).

For any of the variables the factor block $(P>0.10)$ was significant, so it was removed from statistical model. Table 2 shows the changes in $\mathrm{pH}$, NDF, $\mathrm{ADF}$, hemicellulose and lignin due steam explosion, compared to untreated forages. No interactions were detected on $\mathrm{pH}$ or the content of the fiber fractions. In contrast, the factor forage interacted with pressure or time on DMIVD.

Cuadro 2. Cambios en el pH y el contenido de las fracciones fibrosas de residuos agrícolas tratados con explosión de vapor

Table 2. Changes in $\mathrm{pH}$ and contents of fibrous fractions of agricultural waste treated with steam explosion

\begin{tabular}{|c|c|c|c|c|}
\hline Variables & $\begin{array}{l}\text { Corn } \\
\text { stover }\end{array}$ & $\begin{array}{l}\text { Sorghum } \\
\text { stover }\end{array}$ & $\begin{array}{c}\text { Sugarcane } \\
\text { bagasse }\end{array}$ & SEM \\
\hline $\mathrm{PH}$ & $-2.9 \mathrm{a}$ & $-2.0^{b}$ & $-2.4^{b}$ & 0.04 \\
\hline \multicolumn{5}{|c|}{ Percentage units (dry base) } \\
\hline Neutral detergent fiber & $-16.7^{a b}$ & $-14.4^{b}$ & $-19.7^{a}$ & 1.07 \\
\hline Acid detergent fiber & $-1.8 b$ & $-1.0^{b}$ & $-6.0^{a}$ & 0.93 \\
\hline Hemicellulose & -18.5 & -15.3 & -13.7 & 1.46 \\
\hline Cellulose & -2.8 & -2.7 & -2.8 & 0.45 \\
\hline Lignin & $0.6 \mathrm{~b}$ & $0.7 \mathrm{~b}$ & $-2.1^{a}$ & 0.16 \\
\hline
\end{tabular}

$\mathrm{SEM}=$ standar error of the mean.

a,b,c Values with distint superscript are different $(P<0.01)$. 
Los análisis de laboratorio consistieron en la determinación de la materia seca $\left(100{ }^{\circ} \mathrm{C}\right.$ durante toda la noche), materia orgánica $\left(600{ }^{\circ} \mathrm{C}\right.$ por $\left.4 \mathrm{~h}\right)$, las fracciones de fibra y lignina $72 \% \mathrm{H}_{2} \mathrm{SO}_{4}(28)$. La hemicelulosa se calculó como la diferencia entre los contenidos de FDN y FDA. La determinación del $\mathrm{pH}$ de los forrajes tratados se realizó de acuerdo a Tejada ${ }^{(29)}$ con el uso de un potenciómetro (Orion Mod 720A) calibrado en el rango de $\mathrm{pH}$ entre 4 a 7.

\section{RESULTADOS Y DISCUSIÓN}

En el Cuadro 1 se presenta la composición química de los residuos agrícolas sin tratar. Se aprecia que los tres forrajes tienen un alto contenido de fibra detergente neutro, especialmente el BZC, más del $89 \%$ de la materia seca. En concordancia con el alto contenido de fibra, tiene una baja digestibilidad in vitro (DIVMS) en comparación con RM o RS. No obstante, los coeficientes de DIVMS para RM y BZC son mayores a los mencionados en otros estudios $(30,31)$. Esta diferencia se podría explicar porque el método con bolsas filtro de Ankom da valores más altos de digestibilidad que el método con tubos de Tilley and Terry(32).

Para ninguna de las variables de estudio se detectó que el factor bloque o sesión $(P>0.10)$ fuera significativo, por esto se eliminó del análisis estadístico. En el Cuadro 2 se muestran los cambios en el pH, FDN, FDA, hemicelulosa y lignina por efecto de la explosión de vapor, respecto a los forrajes sin tratar. No se detectaron interacciones entre los factores de estudio en $\mathrm{pH}$ del forraje tratado o en el cambio en el contenido de las fracciones de fibra. En contraste, presión y tiempo interactuaron con el forraje en la DIVMS.

El material tratado con EXPV es ácido; redujo el pH entre 2 a 2.9 unidades. La mayor reducción se observó en RM tratado (-2.9); mientras en RS (-2.0) y BZC (-2.4), la reducción fue similar pero de menor magnitud.

Respecto a las fracciones de fibra, la EXPV redujo $(P<0.01)$ el contenido de FDN en los tres forrajes
The material treated with STE was acid; $\mathrm{pH}$ was reduced between 2 to 2.9 units compared to the untreated material. The greatest reduction in $\mathrm{pH}$ was observed in treated COS (-2.9), while in SOS $(-2.0)$ and SUB (-2.4), the reduction was similar but of lesser magnitude.

With respect to fiber fractions, STE reduced $(P<0.01)$ NDF content in the three forages in 19.7, 16.7 and 14.4 percentage units (PU) for SUB, COS and SOS, respectively. The reduction in COS was intermediate with no statistical differences regarding SUB or SOS. However, the change (-15.8 PU) in the hemicellulose was similar among forages. The reduction of the hemicellulose and NDF correlated at $\mathrm{r}=0.72(P<0.01)$, suggesting that part of the reduction of NDF is explained by the hemicellulose solubilization.

Although no changes in the ADF content in COS and SOS were detected, in sugarcane ADF decreased $(P<0.01)$ in six PU. In contrast, cellulose was resistant to STE because no changes were detected in any of the three forages.

On the lignin content, contrasting results were obtained. In SUB, the lignin decreased $(P<0.01)$ in only $2.1 \mathrm{PU}$, but increased $(P<0.01)$ at $0.66 \mathrm{PU}$ for COS and SOF, with no difference between these forages.

The effects of pressure and time are presented in Table 3. As the vapor pressure increased, the $\mathrm{pH}$ of treated forage was decreasing linearly $(P<0.01)$, and with the application time of the STE, the $\mathrm{pH}$ decreased quadratically $(P<0.02)$. While the reduction of NDF shows a linear trend $(P<0.01)$ at increased pressure, but with increasing application time of the STE, NDF was quadratically reduced $(P<0.02)$. In contrast, the hemicellulose was linearly decreased $(P<0.01)$ with increasing in pressure or application time of the STE. No changes were detected in ADF, cellulose or lignin contents with pressure levels or application time of the STE.

Acidification of the treated materials can be explained by the generation of organic acids during 
Cuadro 3. Efecto de la presión (P) o tiempo $(\mathrm{T})$ sobre el cambio de pH y de la composición de los residuos agrícolas tratados con explosión de vapor

Table 3. Effect of the pressure $(\mathrm{P})$ or time $(\mathrm{T})$ on the change of $\mathrm{pH}$ and the composition of agricultural waste treated with steam explosion

\begin{tabular}{|c|c|c|c|c|c|c|c|c|c|c|c|c|}
\hline \multirow[b]{4}{*}{ Variables } & \multicolumn{9}{|c|}{ Time (min) } & \multirow[b]{4}{*}{ SEM } & \multirow{3}{*}{\multicolumn{2}{|c|}{ Effecta }} \\
\hline & & 5 & & & 10 & & & 15 & & & & \\
\hline & \multicolumn{9}{|c|}{ Pressure $\left(\mathrm{kg} \mathrm{cm}{ }^{2}\right)$} & & & \\
\hline & 10.3 & 13.8 & 17.2 & 10.3 & 13.8 & 17.2 & 10.3 & 13.8 & 17.2 & & $\mathrm{P}$ & $\mathrm{T}$ \\
\hline $\mathrm{pH}$ & 1.87 & 2.30 & 2.47 & 2.16 & 2.56 & 2.83 & 2.39 & 2.58 & 2.80 & 0.04 & $\mathrm{~L}$ & Q \\
\hline \multicolumn{13}{|c|}{ Percentage units (dry base) } \\
\hline NDF & 7.9 & 15.7 & 16.7 & 13.1 & 19.5 & 24.3 & 14.8 & 19.7 & 21.1 & 0.01 & $\mathrm{~L}$ & Q \\
\hline ADF & 1.7 & 2.3 & 5.1 & 5.1 & -0.4 & 1.2 & 0.9 & -1.0 & -0.6 & 0.01 & ns & ns \\
\hline Hemicellulose & 6.2 & 13.3 & 15.3 & 8.1 & 19.9 & 23.1 & 14.8 & 20.0 & 21.7 & 0.02 & $\mathrm{~L}$ & $\mathrm{~L}$ \\
\hline Cellulose & 3.2 & 2.0 & 4.1 & 3.0 & 1.8 & 2.9 & 3.0 & 2.5 & 2.7 & 0.45 & ns & ns \\
\hline Lignin & 0.3 & 0.6 & -0.1 & 0.4 & -0.1 & 0.6 & 0.5 & 0.2 & -0.3 & 0.16 & ns & ns \\
\hline IVDDM & 6.5 & 14.9 & 11.3 & 9.7 & 17.7 & 19.0 & 12.0 & 16.3 & 16.0 & 1.09 & $q$ & $q$ \\
\hline
\end{tabular}

$\mathrm{SEM}=$ Standard error of the mean.

a Factor effect: lineal $(\mathrm{L} ; P<0.01)$, quadratic $\mathrm{Q}(P<0.02)$ or $\mathrm{q}(P<=0.06)$.

$\mathrm{ns}=$ non significant $(P>0.06)$.

en 19.7, 16.7 y 14.4 unidades porcentuales (UP) para BZC, RM y RS, respectivamente. La reducción en RM fue intermedia sin diferencias estadísticas respecto al BZC o RS. Sin embargo, el cambio (-15.8 UP) en la hemicelulosa fue similar entre forrajes. La reducción de la hemicelulosa y de la FDN se correlacionaron significativamente, $\mathrm{r}=0.72$ $(P<0.01)$, lo que sugiere que parte de la reducción de la FDN se explica por la solubilización de la hemicelulosa.

Aunque no se detectaron cambios en el contenido de FDA para RM y RS por efecto de la EXPV, en BZC la FDA se redujo $(P<0.01)$ en sólo seis UP. La celulosa fue más resistente a la EXPV porque no se detectaron cambios en ninguno de los tres forrajes.

Respecto al contenido de lignina, se obtuvieron resultados contrastantes. En el BZC la lignina se redujo $(P<0.01)$ en sólo $2.1 \mathrm{UP}$, pero se incrementó $(P<0.01)$ en 0.66 UP para RM y RS, sin diferencias entre estos forrajes.
STE. The steam degrades hemicellulose and acetyl groups of xylose are released and these are converted to acetic acid. It has been reported that 60 to $70 \%$ of xylose residues may show acetyl groups in forages, and that the amount of acetic acid released can reach $6 \mathrm{~g}$ per $100 \mathrm{~g}$ dry wood treated with steam $^{(33)}$. Although differences in the degree of acidity could be explained primarily by the degree of hemicellulose acetylating, this was not determined in this work, nor was information found.

Besides the release of acid during the STE, the change in $\mathrm{pH}$ can be explained by loss of cation exchange groups (CEG) which relate to the buffering capacity of the fiber ${ }^{(28)}$. McBurney et al ${ }^{(34)}$ reported that steam-treated wood was one of the lowest CEG values (64 mmol $\mathrm{kg}$ cell wall) in a list of different forages, although authors did not specify the conditions of hydro-thermal treatment. Van Soest et al(28) also suggest a positive relationship between lignin content and number of CEG groups. It had been reported that lignin degrades at temperatures above $180{ }^{\circ} \mathrm{C}^{(35)}$ or when applying a vapor pressure 
Los efectos de presión y tiempo se presentan en el Cuadro 3. Según se incrementó la presión del vapor, el $\mathrm{pH}$ del forraje tratado fue decreciendo linealmente $(P<0.01)$ y con el tiempo de aplicación de la EXPV, el pH disminuyó en forma cuadrática $(P<0.02)$. Mientras que la reducción de FDN muestra una tendencia lineal $(P<0.01)$ al incremento de la presión, pero con el incremento en el tiempo de aplicación de la EXPV, la FDN se reduce en forma cuadrática $(P<0.02)$. En contraste, la hemicelulosa se redujo linealmente $(P<0.01)$ con el incremento de los factores de presión o tiempo de aplicación de la EXPV. Dentro de los niveles de presión o tiempo, no se detectaron cambios en el contenido de FDA, celulosa y lignina.

La acidificación de los materiales tratados puede explicarse por la generación de ácidos orgánicos durante la degradación de la hemicelulosa. Durante la EXPV los grupos acetilo de las xilosas son liberados y estos se convierten en ácido acético. Se ha reportado que entre 60 al $70 \%$ de los residuos de xilosas pueden presentar grupos acetilos en forrajes, y que la cantidad de ácido acético liberado puede alcanzar $6 \mathrm{~g}$ por $100 \mathrm{~g}$ de madera seca tratada con vapor ${ }^{(33)}$. Aunque las diferencias en el grado de acidez podrían ser primariamente explicadas por el grado de acetilización de la hemicelulosa; esto no se realizó, ni se encontró información al respecto.

Además de la liberación de ácidos durante la EXPV, el cambio en el $\mathrm{pH}$ puede explicarse por la pérdida de grupos intercambiadores de cationes (ICC) que se relacionan con la capacidad amortiguadora de la fibra(28). Aunque no especificaron las condiciones del tratamiento hidro-térmico, McBurney et al(34) reportaron que la madera tratada con vapor tenía uno de los valores más bajos de CIC (64 mmol kg pared celular) en una lista de diferentes forrajes. Van Soest et al(28) también sugieren que existe una relación positiva entre el contenido de lignina y número de grupos ICC. Se ha reportado que la lignina se degrada a temperaturas mayores a 180 ${ }^{\circ} \mathrm{C}^{(35)}$ o cuando se aplica una presión de vapor de $15.3 \mathrm{~kg} / \mathrm{cm}^{2}$ por $4.5 \mathrm{~min}^{(36)}$, lo cual sugiere que las combinaciones de presión y tiempo utilizadas of $15.3 \mathrm{~kg} / \mathrm{cm}^{2}$ for $4.5 \mathrm{~min}^{(36)}$, suggesting that combinations of pressure and time used in this study were able to degrade lignin, so that the buffer capacity could diminish more. However, in SUB, the lignin content was reduced by only $17 \%$ (2.1 PU), but in COS and SOS, the lignin increased $11 \%$ (0.63 PU). According to Sun et al ${ }^{(15)}$, between 11 to $12 \%$ of the total lignin is degraded during STE, but then, lignin undergoes reactions of re-condensation and is re-located on the micro-fibers of cellulose $(13,15)$. These changes may explain the variations noted; however, the magnitude may differ among forages. Although lignin is re-located in the micro fibers of cellulose, it is possible that the buffering capacity of the treated forage is not restored. It is also possible that the lignin increase in SOS and COS is due to Maillard reactions during $\operatorname{STE}^{(1)}$.

The amount of hemicellulose removed by hydrothermal treatments has been variable and has not been related directly to severity of STE. When wheat straw treated with a STE severity of 4.2, Viola et al(37) reported that only $50 \%$ of the hemicellulose was solubilized. In contrast, using a 3.5 severity, other researchers $(38)$ mentioned that up to $70 \%$ of the hemicellulose of wheat straw was solubilized. Another study(39) reported that 30 to $90 \%$ of corn stover xylan was removed by STE applying a severity scale between 3.3 and 4.3. In the treated residues, SUB hemicellulose was solubilized in $55 \%$; while COS and SOS hemicelluloses were solubilized in a greater extension, 74 and $79 \%$ respectively. These differences in hemicellulose solubilization can be explained because the chemical interaction between the lignin and hemicellulose, varies among forages. For example, it has been determined that the number of ester bonds between carbohydrates chains and lignin varies by specie and maturity, among others factors $(40)$.

The DMIVD was the only variable on what interactions were detected. The interactions were fodder*application time $(P<0.02$, Figure 1) and fodder*pressure $(P<0.06$, Figure 2$)$. The DMIVD of SUB was improved linearly with increasing application time or pressure. In contrast, DMIVD 
en este estudio pudieron degradar la lignina. Sin embargo, en el BZC, el contenido de lignina se redujo en apenas $17 \%$ (2.1 UP), pero en RM y $\mathrm{RS}$, el contenido de lignina se incrementó en aproximadamente $11 \%$ (0.63 UP). De acuerdo con Sun et al ${ }^{(15)}$, entre 11 a $12 \%$ de la lignina total es degradada durante la EXPV, pero enseguida, la lignina sufre reacciones de re-condensación y es re-localizada sobre las micro-fibras de celulosa $(13,15)$. Estos cambios pueden explicar las variaciones mencionadas; sin embargo, la magnitud de los cambios puede diferir entre forrajes. Aunque la lignina sea re-localizada en las micro-fibras de celulosa, es posible que la capacidad amortiguadora de los forrajes tratados no se restaure. Se puede sugerir que en el RM y RS que el incremento de lignina se debe a reacciones de Maillard durante la EXPV(1).

Aunque la hemicelulosa es solubilizada por ácidos y álcalis, la cantidad de hemicelulosa removida por los tratamientos hidro-térmicos ha sido variable. Mientras en la paja de trigo tratada con EXPV con una severidad $=4.2$, Viola et al ${ }^{(37)}$ reportaron que sólo $50 \%$ de la hemicelulosa fue solubilizada. En contraste, utilizando una severidad 3.5, investigadores(38)

Figura 1. Interacción tiempo*forraje en la digestibilidad in vitro de forraje tratados con explosión de vapor

Figure 1. Interaction time*forage on in vitro digestibility of feed treated with steam explosion

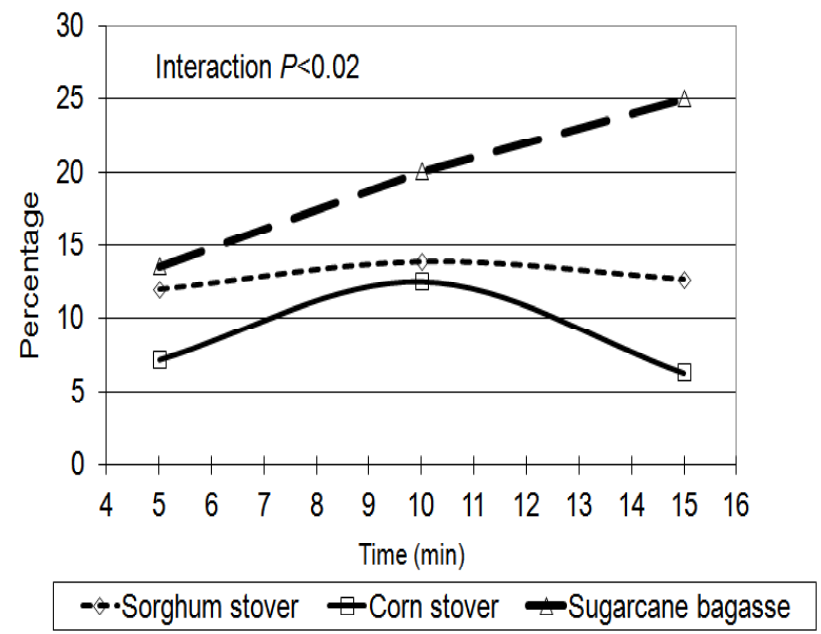

of COS and SOS were enhanced in quadratic shape with the increase of the pressure or the application time. The quadratic trend can be related to an increased presence of inhibitor compounds, such as phenols $(41,42)$, that are released in higher extension as the severity of STE is greater. The total content of phenols compounds reported is $0.28^{(43)}, 1.35^{(44)}$ and $0.52^{(45)} \mathrm{g} / 100 \mathrm{~g}$ for COS, SOS and SUB, respectively. Another possibility is that as hemicellulose is solubilized, the proportion of crystalline cellulose increases, resulting in lower digestibility.

To estimate the point where the effect of pressure or application time on DMIVD change maximizes, the first derivative of the quadratic equations for COS or SOS was obtained. The DMIVD was maximized at 14.2 and $14.3 \mathrm{~kg} \mathrm{~cm}^{2}$ of pressure or with 9.9 and 10.6 min of application of the STE for COS and SOS, respectively.

\section{Kinetics of in situ digestion}

The increase in the NDF fraction A can be explained by the solubilization of hemicellulose and also by a reduction of particle size ${ }^{(46)}$ of treated fodder

Figura 2. Interacción presión^forraje en el cambio de la digestibilidad in vitro de la MS de forrajes tratados con explosión de vapor

Figure 2. Interaction pressure*forage of the in vitro digestibility change of forages treated with steam explosion

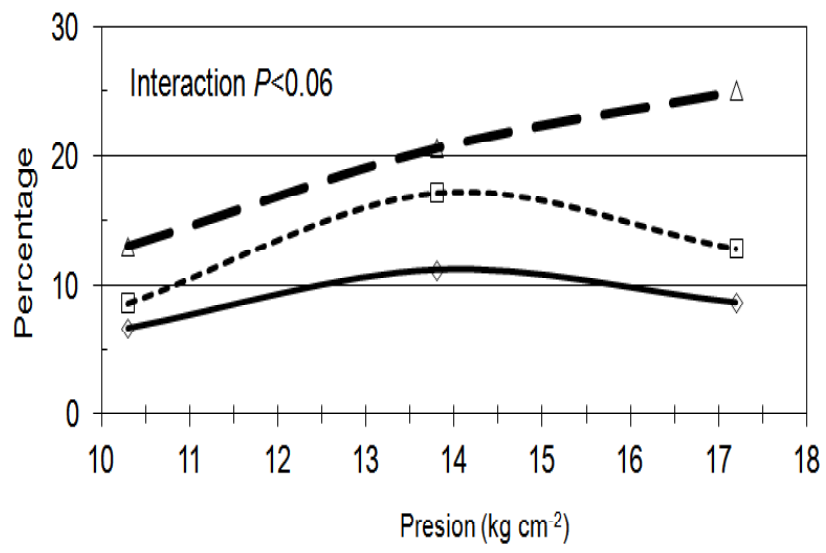

-Sorghum stover - -G.Corn stover $\quad$-Sugarcane bagasse 
señalaron que hasta $70 \%$ de la hemicelulosa de la paja de trigo fue solubilizada. En otro estudio(39) reportaron que entre 30 al $90 \%$ del xilano del rastrojo de maíz fue removido por EXP cuando se aplicó una escala de severidad entre 3.3 y 4.3. En los forrajes tratados, la hemicelulosa del BZC se solubilizó en $55 \%$; la hemicelulosa del RM y RS se solubilizaron en una mayor extensión, 74 y 79 $\%$ respectivamente. Estas diferencias en la solubilización de la hemicelulosa se pueden explicar porque la interacción química entre la lignina y hemicelulosa varía entre forrajes. Por ejemplo, se ha determinado que el número de uniones ester entre cadenas de carbohidratos y la lignina varía por efecto de especie y madurez, entre otros $(40)$.

El cambio de la DIVMS por efecto de EXPV fue la única variable en la cual interactuaron la presión
(Table 4). The change in the hemicellulose content (Table 3) by STE explains 100, 80 and $50 \%$ of the increase of the fraction A of the NDF of $\mathrm{BCZ}$, COS and SOS, respectively.

The observed changes in the fraction A of FDA and cellulose followed similar trends as FDN. However, increasing the fraction A of the FDA $(P<0.05)$ is not easily explained because the cellulose remains insoluble after treatment with steam $^{(47,48)}$. Moreover, the degradation of cellulose occurs when using pressure above $28 \mathrm{~kg}-1 \mathrm{~cm}^{2(46)}$, which is higher than the pressures used in this study. Then, the apparent increase in fraction A could be explained because the change in particle size.

In the potentially fermentable or digestible fraction (FPD) of the FDN, there were contrasting trends,

Cuadro 4. Cambios por efecto de la explosión de vapor en los parámetros de la cinética de la digestión de las fracciones de fibra (NDF y ADF) de forrajes tratados

Table 4. Changes as a result of the explosion of steam on parameters of kinetics of digestion fractions of fibre (NDF and $A D F)$ treated forage

\begin{tabular}{|c|c|c|c|c|c|c|c|c|c|c|c|c|}
\hline & \multicolumn{4}{|c|}{ Corn stover } & \multicolumn{4}{|c|}{ Sorghum stover } & \multicolumn{4}{|c|}{ Sugarcane bagasse } \\
\hline & \multicolumn{8}{|c|}{ Parameters } & & & & \\
\hline & $A$ & $B$ & DR & LT & $A$ & $B$ & DR & LT & A & B & DR & LT \\
\hline \multicolumn{13}{|l|}{ NDF: } \\
\hline Control & 14.1 & 58.7 & 0.042 & 1.8 & 14.4 & 55.9 & 0.034 & 3.7 & 13.6 & 32.7 & 0.030 & 4.4 \\
\hline Change & 24.8 & -10.5 & 0.008 & -1.3 & 38.4 & -18.9 & -0.004 & -1.1 & 21.1 & 12.7 & 0.012 & -3.6 \\
\hline $\mathrm{AEE}^{2}$ & 1.6 & 1.9 & 0.003 & 0.9 & 1.7 & 2.7 & 0.005 & 1.9 & 1.0 & 1.5 & 0.003 & 1.2 \\
\hline $\mathrm{Ho}=0^{3}$ & * & * & * & ns & * & * & ns & ns & * & * & * & * \\
\hline \multicolumn{13}{|l|}{ ADF: } \\
\hline Control & 17.9 & 50.2 & 0.051 & 3.3 & 19.4 & 50.3 & 0.038 & 3.8 & 15.8 & 29.2 & 0.035 & 5.9 \\
\hline Change & 30.9 & -14.4 & 0.011 & -0.9 & 34.6 & -21.9 & 0.010 & -0.8 & 24.0 & 11.8 & 0.006 & -3.6 \\
\hline AEE & 1.3 & 2.2 & 0.008 & 1.0 & 1.4 & 2.8 & 0.009 & 1.4 & 0.9 & 2.1 & 0.009 & 1.2 \\
\hline $\mathrm{Ho}=0$ & * & * & ns & ns & * & * & ns & ns & * & * & ns & * \\
\hline \multicolumn{13}{|l|}{ Cellulose: } \\
\hline Control & 17.6 & 54.0 & 0.058 & 4.2 & 17.9 & 56.5 & 0.041 & 3.9 & 14.2 & 38.7 & 0.029 & 3.2 \\
\hline Change & 29.9 & -13.6 & 0.005 & -1.6 & 36.1 & -25.5 & 0.005 & -0.3 & 23.2 & 9.5 & 0.011 & -2.6 \\
\hline AEE & 1.3 & 2.4 & 0.009 & 1.1 & 3.6 & 0.011 & 1.6 & 1.4 & 1.2 & 2.7 & 0.005 & 1.1 \\
\hline $\mathrm{Ho}=0$ & * & * & ns & ns & * & * & ns & ns & * & * & * & * \\
\hline
\end{tabular}

$\mathrm{A}=$ Fraction that disappears in time zero (percentage units), $\mathrm{B}=$ Fraction potentially digestible at $120 \mathrm{~h}$ (percentage units), $\mathrm{DR}=\mathrm{Digestion}$ rate of first order $\% \mathrm{~h}^{-1}$ ) y $\mathrm{LT}=\mathrm{Lag}$ time (h).

AEE=Asymptotic standard error. (Schabenberger y Pierce, 2002).

Ho=Null hypothesis, * indicates that Ho fue rejected and the change in the parameter is different from zero $(P<0.05)$; ns: non significant. 
o el tiempo con el forraje. Las interacciones fueron forraje*tiempo $(P<0.02$, Figura 1$)$ y forraje*presión $(P<0.06$, Figura 2). Las interacciones consisten en que la DIVMS del BZC se mejoró linealmente con los incrementos en el tiempo de aplicación o la presión. En contraste, se observó un efecto cuadrático en el cambio en DIVMS del RM o de la RS al incremento de los factores presión y tiempo de aplicación. La tendencia cuadrática puede estar relacionada a una mayor presencia de compuestos inhibidores, tales como compuestos fenólicos $(41,42)$ que se incrementan según aumenta la severidad de la EXPV. El contenido total de compuestos fenólicos reportados son $0.28^{(43)}, 1.35^{(44)}$ y $0.52^{(45)} \mathrm{g} / 100 \mathrm{~g}$ para RM, RS y BZC. Otra posibilidad es que en el material tratado al solubilizarse la hemicelulosa, se incrementa la proporción de celulosa cristalina que se digiere más lentamente.

Para estimar el punto donde se maximiza el efecto de la presión o tiempo de aplicación en el cambio de DIVMS, se obtuvo la primera derivada de las ecuaciones cuadráticas para RM o RS. La DIVMS se maximizó en 14.2 y $14.3 \mathrm{~kg} \mathrm{~cm}^{2}$ de presión o con 9.9 y 10.6 min de aplicación de la EXPV para $\mathrm{RM}$ y RS, respectivamente.

\section{Cinética de la digestión in situ}

El incremento en la fracción A de las FDN se puede explicar por la solubilización de hemicelulosa y, además, por una reducción del tamaño de partícula(46) de los forrajes tratados (Cuadro 4). El cambio en el contenido de hemicelulosa por EXPV explicaría 100, 80 y $50 \%$ del incremento observado de la fracción A de la FDN para BCZ, RM y RS, respectivamente.

Los cambios observados en la fracción A de FDA y celulosa siguen similares tendencias que FDN. Sin embargo, el incremento de la fracción A de la FDA $(P<0.05)$ no se explica fácilmente, porque la celulosa permanece insoluble después del tratamiento con vapor ${ }^{(47,48)}$. Además, la degradación de la celulosa ocurre cuando se utilizan presiones por encima de $28 \mathrm{~kg}^{-1} \mathrm{~cm}^{2}$ (46), que es superior a las presiones utilizadas en el presente estudio. because while in SUB, the FPD was increased by 12.7 percentage units, the FPD of COS and SOS were reduced by 10.5 and 18.6 PU, respectively. In the FPD, SUB increase may be related to increased exposure of micro-fibrils of cellulose, but in the COS and SOS a significant fraction of the original FPD may have been solubilized and, moreover, the FPD in forage treated could be constituted by a larger proportion of crystalline cellulose and lignin.

\section{Digestion rate $(\mathrm{DR})$}

It has been suggested that the physical characteristics of the cell wall matrix are more related to the DR than hemicellulose and lignin contents in the cell walls ${ }^{(7)}$. DR may increase because the reported changes in fodder during STE treated, among others, degradation of hemicelluloselignin matrix, pore size increase of the micro fibrils, reduction of the pulp rate crystallization ${ }^{(6)}$ and the substitution of acetyl groups of the hemicellulose(5).

The DR for NDF of COS and SUB, and DR of cellulose in the SUB were increased $(P<0.05)$ by the effect of STE. In contrast, STE did not affect any of the DR of the fiber fractions in the SOS.

No studies were found that determine the DR (\% $\mathrm{h}^{-1}$ ) of low quality forages treated with STE or other hydro-thermal treatment. Regarding the use of chemicals on the DR, the results have been conflicting. In studies with favorable results, Darcy and Belyea ${ }^{(49)}$ mentioned that the delignification of orchard grass (> $77 \% \mathrm{NDF}$ ) with permanganate increased the DR of cellulose digestion from 0.22 to $0.72 \% \mathrm{~h}^{-1}$; when hydrogen peroxide was used, the answer depended on the forage treated. Increases in the DR of SUB, stripped cane and wheat straw were $0.017,0.025$ and $0.004 \% \mathrm{~h}^{-1}$, respectively, but the change in the DR of wheat straw was not different from zero ${ }^{(50)}$. Likewise, other studies have not been able to detect changes in the DR by others chemical compounds $(30,51,52)$.

In contrast, Berger et al ${ }^{(1)}$ reported that the DR of the sheet corncob decreased 5.45 to $2.2 \% \mathrm{~h}^{-1}$ when 
En la fracción potencialmente fermentable o digestible (FPD) de la FDN se encontraron tendencias contrastantes, porque mientras que en BZC, la FPD se incrementó en 12.7 unidades porcentuales, la FPD del RM y RS se redujeron en 10.5 y $18.6 \mathrm{UP}$, respectivamente. En el BZC el incremento de FPD se puede relacionar con una mayor exposición de las micro-fibrillas de celulosa, pero en el RM y RS una importante fracción de la FPD original pudo haber sido solubilizada $\mathrm{y}$, por otra parte, la FPD en el forraje tratado pudo estar constituida por una mayor proporción de celulosa cristalina y lignina.

\section{Tasa de digestión (TD)}

Se ha sugerido que las características físicas de la matriz de las paredes celulares están más relacionadas con la tasa de digestión que el contenido de hemicelulosa y lignina de las paredes celulares ${ }^{(7)}$. Debido a los cambios reportados en los forrajes tratados durante la EXPV, entre otros la degradación de la matriz de hemicelulosa-lignina, el incremento en el tamaño de poro de las microfibrillas, la reducción del índice de cristalización de la celulosa(6) y la sustitución de los grupos acetilo de la hemicelulosa(5), se puede esperar que se incremente la TD.

La TD para FDN de la RM y del BZC, y la TD de la celulosa en el BZC, se incrementaron $(P<0.05)$ por el efecto de la EXPV. En contraste, la EXPV no afectó ninguna de la TD de las fracciones de fibra en la RS.

No se encontraron estudios donde se determinara la tasa de digestión (TD, \% $\mathrm{h}^{-1}$ ) de forrajes de baja calidad tratados con EXPV o vapor. Respecto al uso de compuestos químicos sobre la TD, los resultados han sido conflictivos. En estudios con resultados favorables, Darcy y Belyea(49) mencionan que la delignificación del pasto orchard (>77 \% FDN) con permanganato incrementó la tasa de digestión de la celulosa de 0.22 a $0.72 \%$ h-1; cuando se utilizó peróxido de hidrógeno, la respuesta dependió del forraje tratado. Los incrementos en la TD del BZC, caña descortezada the concentration of sodium hydroxide raised from 0 to $8 \%$. It is likely that the hemicellulose has been extensively solubilized in this study, and the insoluble residue has been formed mainly of cellulose and lignin. Although it may also suggest that the high levels of $\mathrm{NaOH}$ used, were able to raise the $\mathrm{pH}$ of the medium and affect microbial activity.

\section{Lag time (LT)}

Numerically, STE reduced LT of all fiber fractions in the three forages (Table 4). However, the reduction was only significant $(P<0.05)$ in SUB. In SOS and COS, the reduction in LT ranged from 0.3 to $1.6 \mathrm{~h}$, but these values were not different from zero $(P>0.05)$.

In a similar study(14), treatment with steam (195 ${ }^{\circ} \mathrm{C}$ for $15 \mathrm{~min}, \mathrm{~S}=3.83$ ) reduced the LT of sugar cane bagasse of 1.52 to $1.08 \mathrm{~h}$. Although the reduction was only $0.44 \mathrm{~h}$, the authors report that was significant, but do not indicate the kinetic model used to estimate the parameters.

As in the DR, the LT response of forage treated with chemical compounds has been variable. Amjed et al ${ }^{(50)}$ reported similar reductions $(1.0 v s .0 .1 \mathrm{~h})$ using alkaline hydrogen peroxide to treat wheat straw or bagasse $(0.9$ vs $1.0 \mathrm{~h})$. In contrast, other authors $(51,53)$ reported a significant reduction in LT $(9 \mathrm{~h})$ when treated wheat straw with alkaline hydrogen peroxide or $4 \%$ anhydrous ammonia. Call the attention, the striking differences in LT of untreated agricultural residues; untreated wheat straw presented a LT of $14 \mathrm{~h}$, which is nearly four times the LT for SUB in the present study.

Finally, there are studies where LT has increased with the use of chemical treatment. Chen et al (54) reported that LT of rice straw increased from 1.37 to $1.92 \mathrm{~h}$ utilizing sodium hydroxide, but detected no effect of ammonium bicarbonate $(1.49 \mathrm{~h})$.

\section{Extent of digestion (120 h)}

Lignifying is one of the main factors affecting digestibility and extent of digestion $(3,55)$. The 
y paja de trigo fueron: $0.017,0.025$ y $0.004 \% \mathrm{~h}^{-1}$, respectivamente; pero el cambio en la TD de la paja de trigo no fue diferente de cero(50). Asimismo, en otros estudios tampoco se ha logrado detectar cambios en la TD por tratamientos químicos $(30,51,52)$.

En contraste, Berger et al ${ }^{(1)}$ reportaron que la TD de la hoja de la mazorca de maíz disminuyó en $5.45 \%$ $\mathrm{h}^{-1}$ a $2.2 \% \mathrm{~h}^{-1}$ cuando se elevó la concentración del hidróxido de sodio del 0 al $8 \%$. Es probable que la hemicelulosa haya sido extensivamente solubilizada en este estudio, y el residuo insoluble haya estado constituido por celulosa y lignina principalmente. Aunque se puede sugerir también que los altos niveles de $\mathrm{NaOH}$ utilizados pudieron elevar el $\mathrm{pH}$ del medio y afectar la actividad microbiana.

\section{Tiempo de retraso (TR)}

Numéricamente, la EXPV redujo la TR de todas las fracciones fibra en los tres forrajes (Cuadro 4). Sin embargo, la reducción fue sólo significativa $(P<0.05)$ en BZC. En RS y RM, la reducción en TR varió entre 0.3 a $1.6 \mathrm{~h}$, pero estos valores no fueron diferentes de cero $(P>0.05)$.

En un trabajo similar(14) se reportó que el tratamiento con vapor $\left(195{ }^{\circ} \mathrm{C}\right.$ por $15 \mathrm{~min} ; \mathrm{S}=3.83$ ) redujo el TR del bagazo de caña de 1.52 a $1.08 \mathrm{~h}$. delignification of orchard grass with potassium permanganate increased the digestion of cellulose from 64 to $94 \%$ after $72 \mathrm{~h}$ of incubation ${ }^{(49)}$. Recent work $(56,57)$ reported increments between 20 to 35 percentage units in the extent of digestion of transgenic alfalfa lines by affecting the expression of enzymes involved in lignin synthesis.

The confidence interval of the extent of digestion for NDF, ADF and cellulose in fodders are shown in Table 5. The STE consistently increased extension to the three fiber fractions of the three fodders. The mean increases in percentage units were: [14.8, 16.6 and 16.4], [19.5, 13.2 and 11.0] and [34.5, 36.6 and 33.7] for NDF, ADF and cellulose in forage [COS], [SOS] and [SUB], respectively.

Changes in the extension are similar to those reported for change in the amount of potentially digestible NDF or increased DMIVD of wheat straw or corn stover treated with $\mathrm{NaOH}$ or different levels of ammonium(30).

Because hemicellulose is the second largest fraction of NDF, solubilization of this may explain the increased extent of NDF digestion. In contrast, increasing the extent of digestion of FDA is explained by an increased exposure of micro-fibrils of cellulose to the action of rumen bacteria and delignification.

Cuadro 5. Intervalos de confianza al 95\% de la extensión de la digestión (120 h) de las fracciones fibrosas de forrajes tratados con explosión de vapor (STE)

Table 5. Confidence intervals at $95 \%$ of the extent of digestion $(120 \mathrm{~h})$ of fibrous fractions of feed treated with steam explosion (STE)

\begin{tabular}{lccccccc}
\hline & & \multicolumn{2}{c}{ FDN } & \multicolumn{2}{c}{ FDA } & \multicolumn{2}{c}{ Cellulose } \\
\cline { 3 - 8 } & & \multicolumn{4}{c}{ Límits (\% digestion) } \\
\cline { 3 - 8 } & Treatment & Low & High & Low & High & Low & High \\
\hline Corn stover & Control & 70.9 & 73.8 & 65.5 & 70.4 & 68.9 & 74.2 \\
& STE & 85.7 & 88.2 & 82.1 & 86.9 & 85.1 & 90.8 \\
Sorghum stover & Control & 68.0 & 70.6 & 67.0 & 71.1 & 71.5 & 76.4 \\
& STE & 85.8 & 91.9 & 78.0 & 86.5 & 78.9 & 90.9 \\
Sugarcane bagasse & Control & 44.0 & 46.3 & 41.9 & 46.9 & 48.6 & 55.6 \\
& STE & 78.5 & 81.0 & 78.9 & 83.1 & 83.0 & 87.5 \\
\hline
\end{tabular}


A pesar de que la reducción fue sólo de 0.44 h, los autores reportan que es significativa, pero no indican el modelo de cinética utilizado para estimar los parámetros.

$\mathrm{Al}$ igual que en la TD, la respuesta en TR de los forrajes tratados con compuestos químicos ha sido variable. Amjed et al (50) reportaron reducciones similares (1.0 vs $0.1 \mathrm{~h})$ con el uso de peróxido de hidrógeno alcalino para tratar paja de trigo o en el bagazo de caña $(0.9 v s 1.0$ h). En contraste, otros auores $(51,53)$ reportaron una importante reducción en TR $(9 \mathrm{~h})$ cuando trataron paja de trigo con peróxido de oxígeno alcalino o amoníaco anhidro al $4 \%$. Es interesante que la paja de trigo sin tratar presentara una TR de $14 \mathrm{~h}$, que es casi cuatro veces la TR para bagazo de caña sin tratar en el presente estudio. Finalmente, hay estudios donde TR se ha incrementado con el uso del tratamiento químico. Chen et al ${ }^{(54)}$ reportaron que TR de la paja de arroz se incrementó de 1.37 h a 1.92 h cuando utilizaron hidróxido de sodio, pero no detectaron efecto por el bicarbonato de amonio (1.49 h).

\section{Extensión de la digestión (120h)}

La lignificación es uno de los principales factores que afectan la digestibilidad y la extensión de la digestión $(3,55)$. La deslignificación de pasto orchrad con permanganato de potasio incrementó la digestión de la celulosa de 64 a $94 \%$ a las 72 h de incubación ${ }^{(49)}$. En trabajos recientes $(56,57)$ se han señalado incrementos entre 20 y 35 unidades porcentuales en la extensión de la digestión de líneas transgénicas de alfalfa, en las cuales se ha afectado la expresión de enzimas involucradas en la síntesis de la lignina.

El intervalo de confianza de la extensión de la digestión para FDN, FDA y celulosa por forraje se muestran en el Cuadro 5. La EXPV incrementó, en forma consistente, la extensión para las tres fracciones de fibra de los tres forrajes. Los incrementos medios, en unidades porcentuales, fueron: [14.8, 16,6 y 16.4]; $[19.5,13.2$ y 11.0$]$ y $[34.5,36.6$ y 33.7$]$ para FDN, FDA y celulosa dentro de forraje $[\mathrm{RM}]$; $[\mathrm{RS}] \mathrm{y}$ [BZC], respectivamente.

\section{CONCLUSIONS AND IMPLICATIONS}

The STE is a method that can be used to improve the DMIVD and kinetics of the digestion of low quality forages. The STE solubilized mainly cell walls, especially hemicellulose (NDF-ADF). Although this fraction disappears linearly with increasing pressure or application time of the STE, the change in the DMIVD is dependent on forage to treat. While digestibility of SUB increased linearly within the range of pressure and time of application used, the DMIVD of SOS and COS were maximized in average at $14.3 \mathrm{~kg} \mathrm{~cm}^{2}$ pressure or at 10.3 min of application time. STE increases the fraction that disappears at zero time and extent of digestion in three fodders treated. The potentially digestible fraction was increased in the fodder with lowest digestibility, SUB, but was reduced in fodders with greater digestibility. Except for the FDN of the SOS, the STE tends to increase digestion rate of the fiber fractions.

End of english version

Los cambios en la extensión son similares a los reportados para el cambio en la cantidad de FDN potencialmente digestible o en el incremento en DIVMS de la paja de trigo o rastrojo de maíz tratados con diferentes niveles de $\mathrm{NaOH}$ o de $\operatorname{amonio}^{(30)}$.

Puesto que la hemicelulosa constituye la segunda fracción más importante de la FDN, la solubilización de ésta puede explicar el incremento en la extensión de su digestión. En contraste, el incremento de la extensión de la digestión de FDA se explica por una mayor exposición de las microfibrillas de celulosa a la acción de las bacterias del rumen.

\section{CONCLUSIONES E IMPLICACIONES}

La EXPV es un método que puede ser utilizado para mejorar la DIVMS y la cinética de la digestión 
de los forrajes de baja calidad. La EXPV solubiliza principalmente las paredes celulares, especialmente la hemicelulosa (FDN-FDA). Aunque esta fracción desaparece linealmente con el aumento de la presión o el tiempo de aplicación de la EXPV, el cambio en la DIVMS depende del forraje a tratar. Mientras la digestibilidad del BZC se incrementó linealmente dentro del rango utilizado de presión y tiempo de aplicación, la DIVMS de la RS y RM fueron maximizados con $14.3 \mathrm{~kg} \mathrm{~cm}^{2}$ de presión por 10 min de aplicación. La EXPV incrementa la fracción que desaparece en el tiempo cero y la extensión de la digestión de los forrajes tratados. La fracción potencialmente digestible de los forrajes se incrementó en el BZC, pero en el RM y RS la fracción potencialmente disminuye. Exceptuando para la FDN de la RS, la EXPV tiende a incrementar la TD de las fracciones de fibra.

\section{LITERATURA CITADA}

1. Berger LL, Fahey GC Jr, Bourquin LD, Titgemeyer EC. Modification of forage quality after harvest. In: Moser LE, Mertens DR, Collins CM editors. Forage quality, evaluation and utilization. Am Soc Agro, Madison, USA; 1994:922966.

2. NRC. Nutritional Requirements of Beef Cattle. $7^{\text {th }}$ rev ed. Natl Acad Press. Washington, DC; 1996.

3. Van Soest PJ. Nutritional ecology of the ruminant. Ithaca, USA: Cornell University Press; 1994.

4. Carpita NC, Gibeut DM. Structural models of primary cell walls in flowering plants: consistency of molecular structure with the physical properties of the walls during growth. Plant J 1993;3:1-30.

5. Kumar R, Wayman CE. Cellulase adsorption and relationship to features of corn stover solids produced by leading pretreatments. Biotech Bioeng 2009;103:252-267.

6. Chang VS, Holstzapple MT. Fundamental factors affecting biomass enzymatic reactivity. Appl Bioch Biotechnol 2000;8486:5-37.

7. Allen MS, Mertens DR. Evaluating constraints on fiber digestion by rumen microbes. J Nutr 1988;118:261-270.

8. Mosier NC, Wyman B, Dale B, Elander R, Lee YY, Holtzapple M, Ladisch M. Features of promising technologies for pretreatment of lignocellulosic biomass. Bioresour Technol 2005;96:673-686.

9. Sundstøl F, Coxworth EM. Ammonia treatment. In: Sundstø1 F, Owen E. editors. Straw and other fibrous by-products as feed. Elsevier, Amsterdam; 1984:196-247.
10. Martínez AMMA, Soriano TJ, Shimada SA. Crecimiento de borregos Pelibuey alimentados con rastrojo de maíz tratado con amoniaco anhidro. Téc Pecu Méx 1985;48:54-62.

11. Walker HG. Physical treatment. In: Sundst $\varnothing 1$ F, Owen E. editors. Straw and other fibrous by-products as feed. Elsevier, Amsterdam; 1984:79-105.

12. Grous WR, Converse AO, Grethlein HE. Effect of steam explosion pretreatment on pore size and enzymatic hydrolysis of poplar. Enzyme Microb Technol 1986;8:274-280.

13. Kristensen JB, Thygesen LG, Felby C, Jorgensen H, Elder T. Cell-wall structural changes in wheat straw pretreated for bioethanol production. Biotechnol Biofuels 2008;(1):5.

14. Deschamps FC, Ramos LP, Fontana JD. Pretreatment of sugar cane bagasse for enhanced ruminal digestion. Appl Biochem Biotechnol 1996;(57-58):171-182.

15. Sun XF, Xu F, Sun RC, Fowler P, Baird MS. Characteristics of degraded cellulose obtained from steam-exploded wheat straw. Carbohydrate Res 2005;340:97-106.

16. Öhgren K, Galbe M, Zacchi G. Optimization of steam pretreatment of SO2-impregnated corn stover for fuel ethanol production. Appl Biochem Biotechnol 2005;(121-124):10551067.

17. Nakamura Y, Sakada T, Inoue E. Enhanced ethanol production from enzymatically treated steam-exploded rice straw using extractive fermentations. J Chem Technol Biotechnol 2001;76:879-884.

18. Castro FB de, Machado PF. Feeding value steam treated sugar cane bagasse in rumiant rations. Livest Res Rural Develop 1990;2:1-6.

19. Hart MR, Walker HG Jr, Graham RP, Hanni PJ, Brown AH, Kohler GO. Steam treatment of crop residues for increased ruminant digestibility. I. Effects of process parameters. J Anim Sci 1981;51:402-408.

20. Walsum GP van. Severity function describing the hydrolysis of xylan using carbonic acid. Appl Biochem Biotechnol 2001;(91-93):317-329.

21. Lemmon EW, McLinden MO, Friend DG. Thermophysical Properties of Fluid Systems. In Linstrom PJ, Mallard WG editors. NIST Chemistry WebBook, NIST Standard Reference Database Number 69. Nat Inst Stand Technol, Gaithersburg MD, [on line]. http://webbook.nist.gov/chemistry/fluid. Accessed June 17, 2011.

22. Kuehl RO. Design of experiments. Statistical principles of research design and analysis. New York, NY: Ed. Duxbury Press; 2000.

23. Weiss WP. Estimation of digestibility of forages by laboratory methods. In: Moser LE, Mertens DR, Collins CM editors. Forage quality, evaluation and utilization. Am Soc Agro, Madison, USA; 1994:644-681.

24. SAS Institute, Inc. SAS User's Guide: Statistics. Version 9.1 Edition. SAS Institute, Inc., Cary, NC; 2004.

25. Huntington JA, Givens DI. The in situ technique for studying rumen degradation of feeds. A review of the procedure. Nutr Abstr Rev 65B, 2003:63-93.

26. McDonald JM. A revised model for the estimation of protein degradability in the rumen. J Agric Sci Camb 1981;96:251252. 
27. Schabenberger O, Pierce FJ. Contemporary statistical models for the plant and soil sciences. Boca Raton, Fl, USA: CRC Press; 2002.

28. Van Soest PJ, Robertson JB, Lewis BA. Methods for dietary fiber, neutral detergent fiber, and nonstarch polysaccharides in relation to animal nutrition. J Dairy Sci 1991;74:3583-3597.

29. Tejada HI. Control de calidad y análisis de alimentos para animales. México, DF: Ed Sistema de Educación Continua en Producción Animal; 1992.

30. Llamas LG, Santacruz MI, Gómez AR. Respuesta De esquilmos de cereales y leguminosas, y de subproductos del algodón al tratamiento alcalino con amonio $\left(\mathrm{NH}_{3}\right)$ o hidróxido de sodio $(\mathrm{NaOH})$. Téc Pecu Méx 1986;51:68-80.

31. Playne MJ. Increased digestibility of bagasses by pretreatment with alkalis and steam explosion. Biotechnol Bioeng 1984;26:426-433.

32. Wilman DrD, Adegosan A. Comparison of filter bag methods with conventional tube methods of determining the in vitro digestibility of forages. Anim Feed Sci Technol 2000;84:33-47.

33. Maloney MT, Chapman TW, Baker A. Dilute acid hydrolysis of paper birch: kinetic studies of xylan and acetyl-group hydrolysis. Biotechnol Bioeng 1985;27:355-361.

34. McBurney MI; Van Soest PJ; Chase LE. Cation exchange capacity and buffering capacity of neutral detergent fibers. J Sci Food Agric 1983;34:910-916.

35. Chesson A. Mechanistic models of forage cell wall degradation. In: Jung HG, Buxton, DR, Hatfield DR, Ralph J editors. Forage cell wall structure and digestibility. Am Soc Agro, Inc, Madison, Wis., USA; 1993:347-376.

36. Hongzhang $\mathrm{C}$, Liying L. Unpolluted fractionation of wheat straw by steam explosion and ethanol extraction. Bioresour Technol 2007;98:666-676.

37. Viola E, Zimbardi F, Cardinale M, Cardinale G, Braccio G, Gambacorta E. Processing cereal straws by steam explosion in a pilot plant to enhance digestibility in ruminants. Bioresource Technol 2008;99:681-689.

38. Zhang LH, Li D, Wang LJ, Wang TP, Zhang L, Chen XD, Mao Zh. Effect of steam explosion on biodegradation of lignin in wheat straw. Bioresource Technol 2008;99:8512-8515.

39. Yang B, Wyman CE. Effect of xylan and lignin removal by batch and flow through pretreatment on the enzymatic digestibility of corn stover cellulose. Biotechnol Bioeng 2004;86:88-95.

40. Chesson A, Stewart CS, Dalgarno K., King TP. Degradation of isolated grass mesophyll, epidermis and fibre cell walls in the rumen and by cellulolytic rumen bacteria in axenic culture. $\mathrm{J}$ Appl Bacteriology 1986;60:327-336.

41. Varel VH, Jung HJG. Influence of forage phenolics on ruminal fibrolytic bacteria and in vitro fiber digestion. Appl Environ Microbiol 1986;52:275-280.

42. Palmqvist E, Hägerdal BH. Fermentation of lignocellulosic hydrolysates. I: inhibition and detoxification. Bioresource Technol 2000;74:17-24.
43. Egüés I, Sanchez C, Mondragon I, Labidi J. Antioxidant activity of phenolic compounds obtained by autohydrolysis of corn residues. Ind Crop Prod 2012;36:164-171.

44. Sene L, Arruda PV, Oliveira SMM, Felipe MGA. Evaluation of sorghum straw hemicellulosic hydrolysate for biotechnological production of xylitol by Candida guilliermondii. Braz J Microb 2011;42:1141-1146.

45. Martin C, Alriksson B, Sjöde A, Nilvebrant NO., Jönsson LJ. Dilute sulfuric acid pretreatment of agricultural and agroindustrial residues for ethanol production. Appl Biochem Biotech 2007;136-140:339-352.

46. Kim W, Yahaya MS, Goto M. Effects of steam explosion on the chemical composition and rumen degradability of rice (Oryza sativaL.) straw. Grassl Sci 2005;51:139-144.

47. Persson T, Ren JL, Joelsson E, Jönsson AS. Fractionation of wheat and barley straw to access high-molecular-mass hemicelluloses prior to ethanol production. Bioresource Technol 2009;100:3906-3913.

48. Darcy BK, Belyea RL. Effect of delignification upon in vitro digestion of forage cellulose. J Anim Sci 1980;51:798-803.

49. Amjed MH, Jung HG, Donker JD. Effect of alkaline hydrogen peroxide treatment on cell wall composition and digestion kinetics of sugarcane residues and wheat straw. J Anim Sci 1992;70:2877-2884.

50. Oosting SJ, Vlemmix PJM, van Bruchem J. Effect of ammonia treatment of wheat straw with or without supplementation of potato protein on intake, digestion and kinetics of comminution, rumen degradation and passage in steers. Br J Nutr 1994;72:147-165.

51. Haddad SG, Grant RJ, Kachman SD. Effect of wheat straw treated with alkali on ruminal function and lactational performance of dairy cows. J Dairy Sci 1998;81:1956-1965.

52. Haddad SG, Grant RJ, Klopfenstein TJ. Digestibility of alkalitreated wheat straw measured in vitro or in vivo using Holstein heifers. J Anim. Sci 1994;72:3258-3265.

53. Chen XL, Wang JK, Wu YM, Liu JX. Effects of chemical treatments of rice straw on rumen fermentation characteristics, fibrolytic enzyme activities and populations of liquid- and solidassociated ruminal microbes in vitro. Anim Feed Sci Technol 2008;141:1-14.

54. Buxton DR, Russell JR. Lignin Constituents and cell-wall digestibility of grass and legume stems. Crop Sci 1988;28:553558.

55. Shadle G, Chen F, Reddy MSS, Jackson L, Nakashima J, Dixon RA. Down-regulation of hydroxycinnamoyl CoA: shikimate hydroxycinnamoyl transferase in transgenic alfalfa affects lignification, development and forage quality. Phytochemistry 2007;68:1521-1529.

56. Reddy MSS, Chen F, Shadle G, Jackson L, Aljoe H, Dixon RA. Targeted down-regulation of cytochrome P450 enzymes for forage quality improvement in alfalfa (Medicago sativa L.). PNAS 2005;102:16573-16578. 
